\title{
THE SIGNIFICANCE OF ELECTRONIC COMMERCE TO FIRMS' OPERATIONS IN RELATION TO BUSINESS LOCATION: AN EMPIRICAL INVESTIGATION
}

\author{
Uchenna C. Eze \\ Dept. of Economic Geography \\ Nanyang Technological University, Singapore \\ uc_chinwe@hotmail.com \\ A. Lee Gilbert \\ IMARC, Nanyang Business School \\ Nanyang Technological University, Singapore \\ algilbert@ntu.edu.sg
}

\begin{abstract}
Globalization of production and increasing competition spurs greater business use of innovative information systems. As globalization extends its reach over cities and regions, the positions of those places within the emerging global paradigms of regional economies is changing. Only those regions and cities that can mobilize assets for local advantage would succeed. This research examines the implications of location for electronic commerce (EC) role in firm operations through the lens of managerial perceptions of EC systems, EC activities, agglomeration economies, firm-specific features and outputs relative to industry. The input-based view and industrial development frameworks provide the theoretical underpinning for this research. Fully completed instruments from 106 firms in Singapore and Lagos financial services sector, respectively, are the basis of our analysis. Our findings reveal varying results between industries across the two cities, supporting our propositions. Firms with well-configured EC systems are more likely to experience efficiency in EC activities and outputs, given conducive operational conditions. However, firm-specific features were not linked to output, a finding inconsistent with prior studies. Finally, EC business models that focus on operational efficiency strongly complement the historically relevant location variable in industrial operations. These findings provide basis for recommendations to policymakers, practitioners, and researchers.
\end{abstract}

Key Words and Phrases: Electronic Commerce, Business Location, Information Systems Resource-Based View, Singapore, Lagos

\section{INTRODUCTION}

The relentless spread of economic globalization rests on increasing interdependence and interconnectedness among markets, policies, technology diffusion, and production, information, and distribution activities. Our globe "shrinks" with each increase in the capacity and speed of physical and virtual communications, challenging our models of economic geography and conventional business structures. The integration of the World Wide Web (W3) with legacy technology platforms such as electronic data interchange (EDI) affords firms the opportunity to revolutionize and restructure their business processes, reach new marketplaces and collaborate with other firms (Zwass, 2003). As globalization extends its reach over communities, cities and regions, Plummer and Taylor (2000) note that, the positioning of those places within the emerging global paradigm of regional economies shifts. The conventional wisdom is that only those industries, cities and regions that can mobilize assets for local advantage will succeed (Amin and Thrift, 1997, p 155). This model prescribes that local firms must achieve internationally competitive productivity levels to be effective (Plummer and Taylor, 2000). Yet, economic globalization processes may be locally determined and place-specific as well as global (Plummer and Taylor, 2001; Porter, 2000).

We apply the resource-based view and Porter's $(2000,1990)$ frameworks of industrial competitiveness to explore the influence of technology diffusion (in a specific locality) on firm performance. Porter's study of industrial structure and globalization predates the emergence of electronic commerce (EC). It is thus unsurprising that his model does not identify the type of industries that may benefit from the global diffusion of access and use of EC, nor does it suggest whether location plays a role in the potential benefits derivable from the implementation of this recent phenomenon. Nonetheless, his concepts represent a robust background and structural guide for our analysis. 
This exploratory research examines the influence of EC on business operations in relation to specific business environments. Specifically, we developed a conceptual framework to examine management perceptions on the interplay among six constructs, namely; input (EC systems), output, business environment, agglomeration economies, firm-specific features, and EC activity (see Figure 1). Against this backdrop, our paper focuses on EC as a tool that could help industries, cities and regions weather the growing global competitive intensity, and adapt to structural changes in the global economic and geographic landscapes.

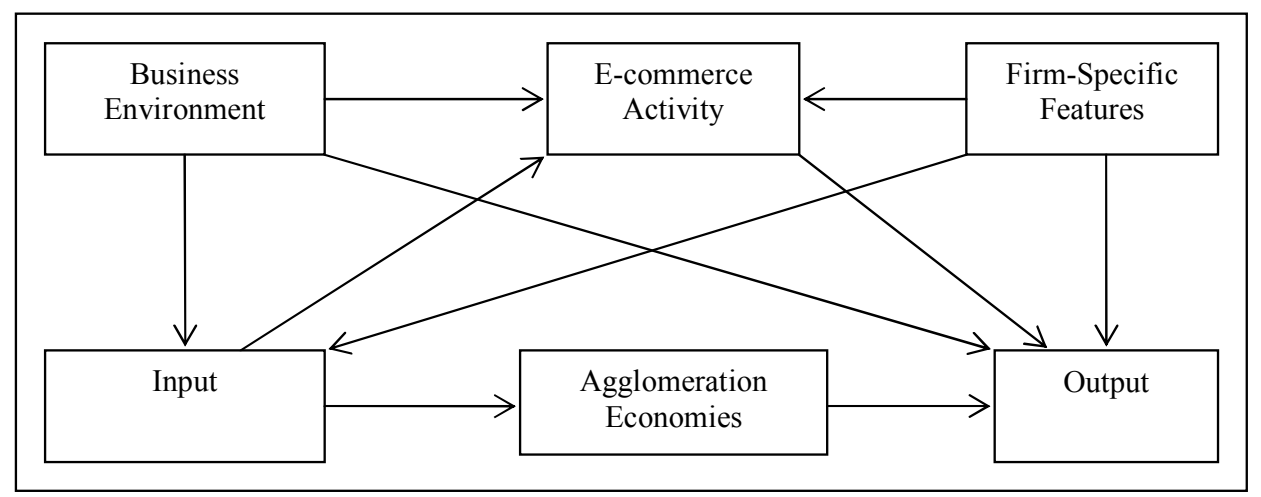

Figure 1: Interplay among the Primary Constructs in the Model

The evidence in this paper draws from field experiences with EC applications among firms operating in two divergent geographic contexts: the equatorial city-state of Singapore and the African city of Lagos. Their deep geographic and economic divergences illuminate the underlying forces we seek to explore. The strategic position the two cities occupy as regional hubs for local and international financial operations influenced the choice of city. Consequently, the results provide relevant policy, research, and practice implications for firms including perhaps future directions for governments with respect to EC framework developments necessary for contemporary competition. To this end, we explore two main questions: (1) How significant are the structural differences/similarities (in terms of input, output, business environment, EC activity, and Firmspecific features) between financial industries in Singapore and Lagos? (2) What sort of relationships exist among input, output, EC activity and firm-specific features of firms in the contexts (city and industry) of this research? The next sections present the conceptual framework, methodology, data analysis and findings, followed by our conclusions.

\section{THE CONTEXT OF EC IN SINGAPORE AND LAGOS}

Singapore lies $137 \mathrm{~km}$ north of the equator and connects to Malaysia by a causeway across the narrow Straits of Johor. With a small population of about, 4.2 million (comprising Chinese $76.7 \%$, Malay $14 \%$, Indian $7.9 \%$, and others $1.4 \%$ ) concentrated in a compact island of about 647.5 square kilometres (sq km.) (land: $637.5 \mathrm{sq} \mathrm{km}$, water: $10 \mathrm{sq} \mathrm{km}$.), Singapore is slightly more than 3.5 times the size of Washington DC and enjoys significant economies of density such as universal communications access for its entirely urban population 4.2 million. The small local market will not sustain capital-intensive EC applications, so local EC initiatives depend on regional markets for expansion and development. The small domestic market also deters firms from adopting new EC applications not already proven in advanced countries such as United States, United Kingdom, Japan, and Australia, out of fear that they may be locked in to technological standards that become obsolete if these larger countries pursue a different standard.

As a small nation-state in Southeast Asia, Singapore is recognized for the quality of its infrastructure supporting the regional operations of multinational firms and more recently as a regional centre for international EC operations (Debreceny et al., 2002; Gilbert et al., 1999). This robust EC 
infrastructure, together with the connected links to major networks in international cities the nation has, and the strengths as a trading hub make Singapore a favourable site for regional EC ventures. Singapore's EC infrastructure comprises e-Payment, e-Security, e-Fulfilment Portals including new generation portals and EC Application Services. The revenue generated by firms from EC infrastructure and supporting services is growing including revenue generated through EC transactions (Tham, 2002). The Singapore government actively boosts the rapid development of EC, encouraging firms to adopt online business models. The government agenda hopes to move over $85 \%$ of its business dealings with firms island-wide to the web by the end of 2004 .

Nigeria is located at the southwestern coast of West Africa, consists of 36 states, and covers an area of $923,768 \mathrm{sq} \mathrm{km}$. Nigeria shares borders with Benin, Cameroon, Chad and Niger (see Figure 3.6). Its population, estimated at 126 million (comprising about 250 recognized groups, many divided into subgroups of considerable social, economic and political significance), is sparsely and densely distributed in rural areas and cities (land: 910,768 sq km, water: 13,000 sq km). Nigeria is about 1426.5 times the size of Singapore or slightly more than twice the size of California which makes it extremely difficult to provide universal communications access to its entire population. Lagos, the specific site for this research, is the industrial and commercial capital of Nigeria in the equatorial region of West Africa regionally known as the growth pole and centre for local/international financial institutions and IT headquarters (Ujah, 1999). Private sector, particularly financial, oil, and telecommunication firms drive EC development in Lagos, unlike Singapore. Quasi-governmental agencies such as the National Communication Commission (NCC) and the Nigeria Internet Group (NIG) provide statutory support for the EC initiatives in Lagos. The government of Nigeria is gradually developing a solid EC infrastructure to enhance operational activities among business partners. Over $75 \%$ of manufacturing and trading firms in Lagos use Electronic Data Interchange (EDI) as their key operating platform. With the rapid diffusion of the Internet, greater numbers of firms are shifting their operations from the proprietary networks of EDI to the W3. As in Singapore, revenue generated from EC support services grows at a geometric rate. EC value was USD8.3 billion in 2002 up $22 \%$ from USD6.8 billion in 2001. Projections for the 2005 EC value stand at USD15 billion, and with the liberalization of the telecommunication sector and the introduction of GSM services, experts predict a boom for EC activities in Lagos. (Ujah, 2001)

\section{CONCEPTUAL FRAMEWORK AND HYPOTHESES}

The resource- or input-based view of the firm responded to the limitations of the structure-conductperformance paradigm of the industrial organization (IO) view of the firm (Bain, 1959; Grant, 1991a). Early input-based theories found the IO view - that a firm's external environment determines its success - to be unrealistic, and turned to the seminal work of Penrose (1959) for inspiration. To counter the IO view, Prahalad and Hamel (1990) developed an input-based theory around the internal competencies of a firm. In their version of input-based theory, competitive advantage lies within a firm, rooted in assets that are valuable and inimitable. A firm's competencies and its managerial abilities to marshal these assets to produce superior performance are the source of its competitive advantage. In the drive to add depth and breadth to this internal view, these theorists noted but left rather vague the role of linkages to a firm's external environment.

Barney (1991) addressed this issue by pinpointing the conditions under which a firm's inputs become valuable by bringing the external environment into the input-based picture. In developing the notion of external environment, he noted that external factors alone do not generate value. However, by nurturing internal competencies and applying them appropriately to the external environment, a firm can create new value. Thus, for a firm's resource to become valuable, it must allow the firm to exploit opportunities and neutralize threats in the firm's environment (Barney, 1991). Conner (1991) made the link between input-based theory, the competitive environment, and firm capabilities more explicit in her comparison of the input-based and IO views. She observed that all three recognize the external constraints of demand, competition, and public policy. For Conner, the task for input-based theorists is to discern the appropriate rent-generating inputs given external (e.g., demand, public policy, and competitor action) and internal (e.g., history, resource endowments, and corporate culture) constraints. Thus, in its current state, the input-based view 
addresses the fit between what firms have the ability to do and what they have the opportunity to do. The interplay with market forces determines the value of resources. A resource that is valuable in a particular industry or at a particular time might fail to have the same value in a different industry or chronological context. In this respect, EC deployment in a firm represents a resource while EC configuration with other resources in the firm is a feature, differentiating the EC capability and the operational EC strategy existing in a firm.

When a firm competes in any industry, it performs discrete but interconnected value-creating activities such as operating a sales force, or delivering products, and these activities have points of connection with the activities of suppliers and customers (Rowson, 1998). We consider EC as a complementary tool firms use to perform these activities more efficiently as opposed to the view characterizing EC as a cannibal that destroys all conventional business models (Porter, 2001). Porter's (1990) view on industrial and national development provides additional theoretical underpinning for this paper. The conceptual model, with deep roots in the resource-based model, integrates much of earlier works in IT and firm, and incorporates the strategic forces unleashed by the rapid diffusion of the Internet. He argued that two sets of determinants affect industrial competitive advantage and, despite the rushing tide of strong globalization, the importance of these factors in determining national competitive and industry capabilities advantage has not diminished, but in fact has become more definite. Among the set of fundamental determinants are factors of production, including human, physical, knowledge, capital resources, and infrastructure. Table 1 depicts the variables used to build the conceptual framework and their respective sources.

Table 1: Variables, Descriptions and Sources

\begin{tabular}{|c|c|c|}
\hline Variables & Descriptions & Sources \\
\hline \multicolumn{3}{|l|}{ Input: } \\
\hline $\begin{array}{l}\text { EC System } \\
\text { Functionality }\end{array}$ & $\begin{array}{l}\text { The richness and navigation functions of the web-page in } \\
\text { terms of interactivity/interface, catalog/commercial } \\
\text { application }\end{array}$ & $\begin{array}{l}\text { Gebauer \& Scharl, 1999; } \\
\text { Zhuang, 2000; Powell and } \\
\text { Dent-Micallef, } 1997\end{array}$ \\
\hline $\begin{array}{l}\text { Expertise EC } \\
\text { application }\end{array}$ & $\begin{array}{l}\text { Availability of requisite skills for managing EC systems and } \\
\text { operations }\end{array}$ & $\begin{array}{l}\text { Zhuang, 2000; Gatian et } \\
\text { al., } 1994\end{array}$ \\
\hline \multicolumn{3}{|c|}{ Business Environment: } \\
\hline Perceived Stability & $\begin{array}{l}\text { Extent of predictability of political, economic and business } \\
\text { situations in the location }\end{array}$ & $\begin{array}{l}\text { Zaheer \& Zaheer, 1997; } \\
\text { Sundell, } 1999\end{array}$ \\
\hline Technology Change & Extent of change in firm and external network systems & Zaheer \& Zaheer, 1997 \\
\hline \multicolumn{3}{|l|}{ Output: } \\
\hline Responsiveness & The quickness with which firms attend to customers & Zaheer \& Zaheer, 1997 \\
\hline Customer Retention & $\begin{array}{l}\text { Expectation of decrease/increase in the share of customers in } \\
\text { the marketplace }\end{array}$ & Gatian, et al., 1995 \\
\hline $\begin{array}{l}\text { Overall Market } \\
\text { Growth }\end{array}$ & General improvement in service provision to customers & Sundell, 1999 \\
\hline EC Activity: & Business activities performed via EC systems & $\begin{array}{l}\text { Zhuang, 2000; Gebauer \& } \\
\text { Scharl, 1999; Literature }\end{array}$ \\
\hline \multicolumn{3}{|c|}{ Firm Specific Features: } \\
\hline Annual Revenue & Annual revenue of the firm for the fiscal year 2000 & Eze, 2004 \\
\hline EC Expenditure & Expenditure on EC and related information systems & Eze, 2004 \\
\hline Period of EC Use & Period of EC use in the firm & Gatian et al., 1995 \\
\hline $\begin{array}{l}\text { Agglomeration } \\
\text { Economies }\end{array}$ & $\begin{array}{l}\text { Sophistication in local assets which enables location of } \\
\text { regional offices of firms and thus the interdependence of } \\
\text { firms based on shared value systems }\end{array}$ & $\begin{array}{l}\text { Plummer \& Taylor, } 2001 \\
\text { Sheppard, 2000; Porter, } \\
1998,1990\end{array}$ \\
\hline
\end{tabular}

No single study motivated our conceptual framework. Previous researches have tested individual paths of the framework we propose. Nonetheless, we place the constructs in a more comprehensive and integrated manner, tracking the course of the deployment and practice of EC in contexts in which it is not studied enough. Figure 2 is a schematic representation of the conceptual framework in this research. There are three main parts in the framework and they are Core Drivers, representing the attributes of the firm in the industry, Economic Structure and EC Influences, and Firm-Level Outcome. 
The Core Drivers, which include input, firm-specific features and business environment, are the independent variables while output denotes the dependent variable. In addition, the EC activity, the economic structure and agglomeration economies are the moderating variables. The firm attributes are Core Drivers because they influence the general EC context in the firm and industry, while input is defined by EC functionality and expertise and is hypothesized to directly impact output. EC activities comprise the routine and core activities. Agglomeration economies are benefits that accrue from geographic proximate group of interconnected firms and associated institutions. Any firm is only one part of a complex chain of production - a series of economic activities held together by linkages among firms (Dicken and Lloyd, 1990). Agglomeration economies derive from shared value systems, location of firms' production/distribution processes in strategic cities, and interdependence of firms for production activities, and we operationalized this variable with two items: the level of linkages of production and marketing activities among firms, and the degree of interdependence of firms in the performance of economic activities.

Figure 2 reveals the elaborate relationships that this research explores. The directions of arrows illustrate the influence of one variable on the other. Propositions 2, 3, and 4 relate directly to the conceptual framework. In addition, we developed Proposition 1 to understand the perceived contextual structures of the constructs and thereby addressing any differences/similarities between the industries in the study areas, which may have operational implications for the relationships among the variables.

Proposition 1: There would be significant positive structural (in terms of Input, Output, EC Activity, Firm-Specific Feature and Business Environment) differences between Singapore and Lagos financial industries, considering the economic and political paths of the two places.

Prior studies (Sundell, 1999; Zaheer and Zaheer, 1997) provide extensive evidence that the influence of EC and information systems on output is mixed. Nevertheless, the conceptual framework illustrates that firms deploying well-configured EC strategy would experience improvements in output in terms of responsiveness, customer retention and overall growth in service provision (Bird and Lerhman, 1993). The conceptual framework depicts that the firm output relates positively to conducive business environment factors in which the firm operates. Prior studies indicate that a business environment characterized as stable and enabling tend to stimulate and encourage improved firm operations (Afuah and Tucci, 2001; Ansoff and Sullivan, 1993; Kettelhut, 1992). Also, previous research on the relationship between uncertainty and output suggests that the two variables are negatively correlated (Downey and Cool, 1982; Waddock and Isabella, 1989). In addition, firmspecific features such as annual revenue base, annual expenditure on EC system and the duration of EC usage in the firm would influence a firm's output. There are extensive prior studies linking the two constructs (Rai, 1997; Zhuang, 2000). This research examines the possibility that adequate firmspecific features positively influence output in the financial industries in the two cities. The framework also depicts that business activities performed via EC systems may influence the output of a firm. Existing research provides specific prior conclusions on the potential impact of EC systems on business activities, and consequently, specific success stories of EC to firms' operations noted by Zhuang (2000), and Hamel and Sampler (1998) served as the bases for this proposition. This paper, therefore, examines the aforementioned using data from two substantive domains Singapore and Lagos. Hence the following proposition: 


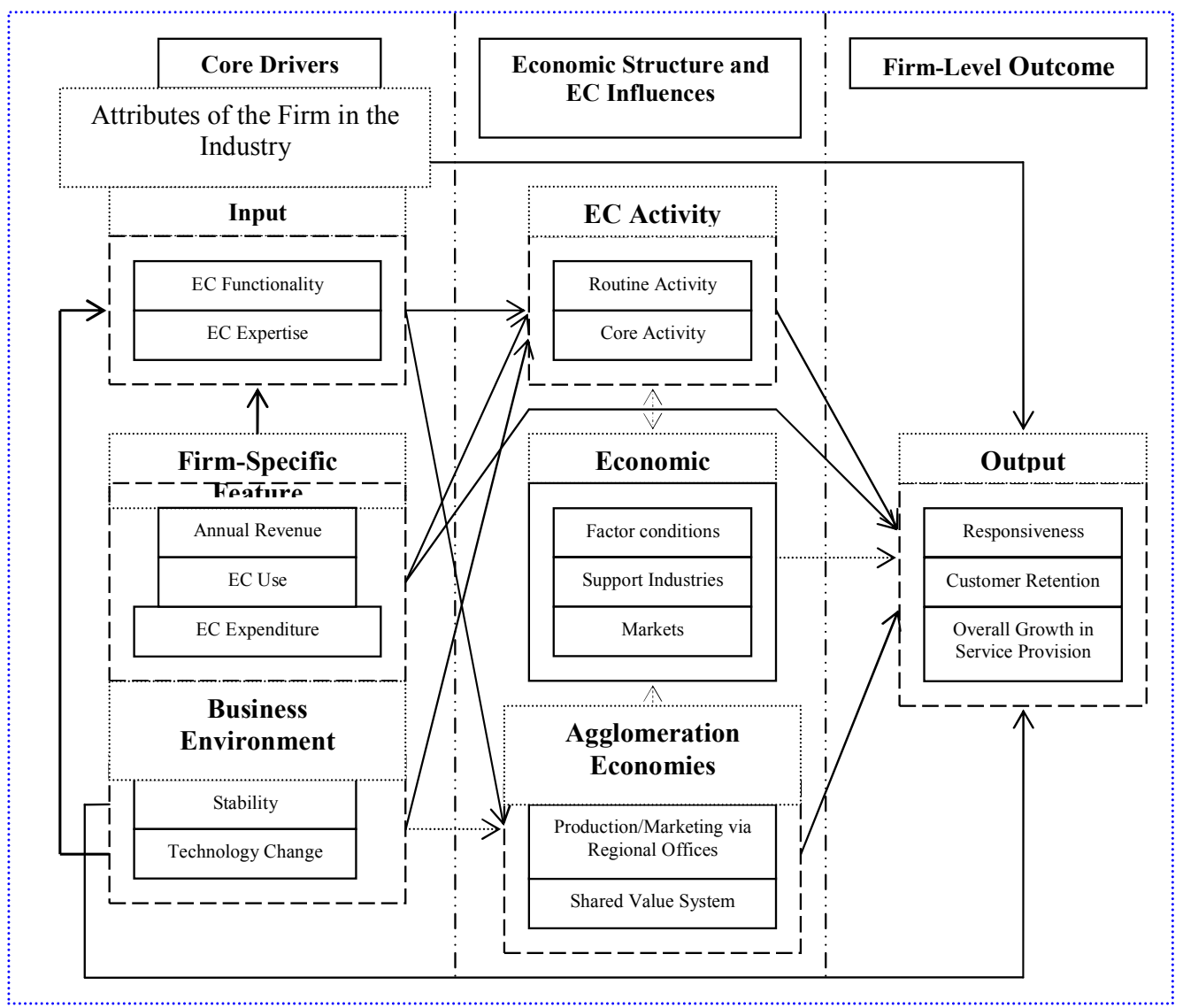

Figure 2: The Detailed Conceptual Framework

Proposition 2: Efficiency in EC activity, firm-specific features, input, and business environment factors would likely have stronger positive influence on output among Singapore firms compared to Lagos firms, considering the economic and political paths of the two places.

The conceptual framework depicts that enabling business environment in which a firm operates would positively influence the structure of input (EC systems and expertise) deployment. This conception contends that the nurturing and development of EC systems in the firm would be high if business environment factors are stable and enabling. Prior research reveals extensive evidence that conducive structure in the business environment would influence positively the deployment of information systems. This paper attempts to provide an expanded understanding by examining the relationships of the two variables in the industries and cities. The conceptual framework also illustrates that firm-specific features such as annual revenue, annual expenditure on EC system and the duration of EC usage in the firm would influence a firm's input. Prior studies indicate linkages between the two constructs (Bird and Lerhman, 1993; Trippi and Salameh, 1989). We, therefore, investigate whether this proposition holds for the financial industries in Singapore and Lagos. The above descriptions set up the next proposition: 
Proposition 3: Efficiency in firm-specific features and business environment factors would likely have stronger positive influence on input among Singapore firms compared to Lagos firms, considering the economic and political paths of the two places.

The conceptual framework also depicts that stability in the business environment would directly relate to efficiency in business activities and operations that a firm performs using EC. Specific literature that demonstrates the relationships between these two variables is scanty. However, firm success stories and experiences from business and economic geography professionals (Gebauer and Scharl, 1999; Hepworth, 1990; Leinbach and Brunn, 2001; Porter, 1990) provide extensive illustrations and predictions regarding the link between EC activities and business environment factors. The conceptual framework also illustrates that firm-specific features would influence EC activity positively. The literature provides extensive review on prior studies linking the two constructs (Gebauer and Scharl, 1999; Rai, 1997). We investigate this proposition using data from firms operating in financial industries in Singapore and Lagos. Also, the framework depicts that the level of sophistication in input factors a firm deploys would have positive implications on the EC activities the firm performs. Prior studies reveal that information systems deployment would positively influence activities an enterprise performs (Gebauer and Scharl, 1999; Zhuang, 2000). This research provides expanded contextual insights on the relationship between EC systems and business activities. Hence the following proposition:

Proposition 4: Efficiency in input, firm-specific features, and business environment factors would likely have stronger positive influence on EC activity among Singapore firms compared to Lagos firms, considering the economic and political paths of the two places.

As we noted earlier, business environmental conditions are major cornerstones in strategic international management, industrial geography and spatial planning. They provide key materials upon which firms conduct, organize their operations, and make concrete decisions on competition. The geographically proximate cluster of independent and informally linked firms and institutions represents a robust organizational form in the continuum between markets and hierarchies (Plummer and Taylor, 2000; Sheppard, 2000). The mere presence of firms, suppliers, and institutions in a location creates the potential for economic value, but it does not necessarily ensure the realization of this potential. Social glue binds clusters together, contributing to the value creation process. Many of the competitive advantages of clusters depend on the free flow of information, the discovery of value-adding transactions, the willingness to align agendas and to work across firms, and strong motivations for improvement. Hence, the following proposition:

Proposition 5: The lack of conducive and sophisticated environmental conditions in a locality such as expertise, capital and infrastructure would likely have a negative effect on agglomeration economies.

\section{METHODOLOGY}

\section{Survey Instrument}

We took several steps to ensure data validity and reliability including pre-tested the instrument with two academics and two business executives selected from the industry. The instrument was then revised for any potentially confusing items. Before the administration of the final survey instruments, the authors called a random subset of 10 respondents for pilot testing to verify if any previously identified concerns with the instrument persisted. Six instruments were returned for a response rate of $60 \%$. Suggestions made during the pre-test for improving the instrument and thus its content validity were addressed before the primary mailings. Further, we used previously validated measurements items (Gebauer and Scharl, 1999; Sundell, 1999; Zhu, 2002) to ensure the validity of the measures; including multiple-item measures for some of the constructs to enhance content coverage. In addition, we computed Cronbach's alpha scores for the overall internal reliability and 
consistency on the Likert Scale questions in the instrument pertaining to input, business environment, EC activities, agglomeration economies, firm-specific features, and output, resulting in alpha scores of 0.71 or higher, which indicates strong internal consistency.

\section{Sample and Participation}

We selected a sample of 289 (160 from Singapore and 129 from Lagos) for this research. The participants were mainly large firms randomly selected from the financial service industry, selected based on the knowledge that firms likely to be successful at obtaining advantages from the use of information systems were those that exhibit evidence of growth (Lee and Adams, 1990). The population frame for the financial firms in Lagos were the List of Registered Businesses in the Lagos Stock Exchange and the Industry Classification provided by Statistics Office of Nigeria. The Directory of Financial Institutions in Singapore provided by Monetary Authority of Singapore (MAS) served as the population frame for the firms in Singapore. The instruments were then mailed to CIOs of the 160 and 129 firms in Singapore and Lagos, respectively. The questions/statements were based, mainly, on a five-point (1-5) Likert point scale. Of the 289 firms surveyed, 106 useable responses were collected (i.e., a response rate of $36.67 \%$ ). There were 58 valid responses from Singapore, (i.e., a response rate of $36.25 \%$ ), while there were 48 useable responses from Lagos (i.e., a response rate of $37.21 \%$ ). Our total response rate of $36.67 \%$ compares favourably with similar firms mail surveys: e.g., McDougall et al. (1994) had 11\% response rate in a study of new technology-based firms; Chandler and Hanks (1994) had a 19\% response rate in a study of manufacturing firms. It is also important to note that although individuals representing the firms provided responses to the instrument, we based the unit of analysis on the firm. In addition, we assessed the potential for non-response bias by comparing early versus late respondents, as advocated by Uma (1992).

\section{Measures and their Psychometric Properties}

We refined the groupings of the instrument items into six measures by a series of confirmatory factor analyses using a structural equations approach (see Table 2). The motivation for the research design was to develop measures with desirable psychometric properties and to eliminate any items not measuring the constructs well (Carmines and Mclver, 1981). 
Table 2: Standardized Coefficients, Estimates, Average Shared Variance and Composite Reliability for the Measurement Model for Singapore and Lagos Samples

\begin{tabular}{|l|c|c|c|c|}
\hline Construct/Indicator & $\begin{array}{c}\text { Standardized Path } \\
\text { Coefficients }\end{array}$ & Estimates & $\begin{array}{c}\text { Average Shared } \\
\text { Variance (\%) }\end{array}$ & $\begin{array}{c}\text { Composite } \\
\text { Reliability }\end{array}$ \\
\hline Input: & & & $67(63)$ & $0.81(0.78)$ \\
\hline EC Functionality & $0.921(0.671)$ & $7.89^{* *}\left(5.98^{* *}\right)$ & & \\
\hline EC Expertise & $0.894(0.594)$ & $8.19^{* *}\left(6.33^{* * *}\right)$ & & \\
\hline Output: & & & $72(75)$ & $0.87(0.91)$ \\
\hline Responsiveness & $0.876(0.496)$ & $7.90^{* *}\left(7.46^{* * *}\right)$ & & \\
\hline Customer Retention & $0.795(0.645)$ & $6.89^{* *}\left(5.34^{* *}\right)$ & & \\
\hline Overall Growth & $0.804(0.657)$ & $7.19^{* *}\left(4.87^{* *}\right)$ & & \\
\hline Business Environment: & & & $83(65)$ & $0.91(0.88)$ \\
\hline Perceived Stability & $0.717(0.733)$ & $5.79^{* *}\left(6.22^{* * *}\right)$ & & \\
\hline Technology Change & $0.871(0.481)$ & $7.11^{* *}\left(5.39^{* *}\right)$ & & $0.82(0.87$ \\
\hline Firm-Specific Features: & & & $68(54)$ & \\
\hline Annual Revenue & $0.891(0.675)$ & $6.35^{* *}\left(5.18^{* *}\right)$ & & \\
\hline EC Expenditure & $0.900(0.551)$ & $7.39^{* *}\left(5.33^{* *}\right)$ & & \\
\hline EC Usage & $0.880(0.630)$ & $6.73^{* *}\left(4.99^{* *}\right)$ & & \\
\hline EC Activity: & & & $75(61)$ & $0.86(0.87)$ \\
\hline Routine Activity & $0.650(0.601)$ & $5.23^{* *}\left(3.77^{* *}\right)$ & & \\
\hline Core Activity & $0.710(0.418)$ & $7.01^{* *}\left(3.26^{* *}\right)$ & & \\
\hline Agglomeration Economies: & & & $65(59)$ & $0.74(0.78)$ \\
\hline Production via overseas office & $0.672(0.672)$ & $5.29^{* *}\left(5.73^{* *}\right)$ & & \\
\hline Shared Value System & $0.613(0.613)$ & $3.95^{*}\left(4.35^{* *}\right)$ & & \\
\hline Values in parentheses are for Lagos $* * p<0.05 * * * *<0.01$ & & & \\
\hline
\end{tabular}

We performed each confirmatory factor analysis using CALIS (covariance analysis of linear structural equations) using maximum likelihood estimation. We also evaluated the fit of the confirmatory factor analysis by subjecting the variables to several tests. The goodness of fit index averaged 0.90 , and when adjusted for the degrees of freedom, averaged 0.85 . The root mean square residual was 0.05 on average, and the significant chi-square statistic had a value of 158.0 with 80 degrees of freedom. The corresponding normed chi-square value was 1.98. Bentler's comparative fit index was 0.96 while Bentler and Bonett's (1980) normed and nonnormed and Bollen's normed and nonnormed indexes ranged from 0.89 to 0.96 . Generally, the fit of the confirmatory factor analysis to the data was satisfactory (Anderson and Gerbing, 1988). Using the results of the final confirmatory factor analysis, we examined the psychometric properties of the measures, which indicate that the measures exhibit satisfactory average shared variance. Table 2 also displays the composites reliability coefficients for the measures and demonstrate satisfactory composite reliability. We dew several conclusions from the discriminant analysis regarding the measures' psychometric properties one of which is that all the measures displayed adequate convergence as measured by these values since the average percentage of shared variance for each measure is larger than $50 \%$. In addition, the measures have satisfactory reliability, since all the reliability coefficients are 0.64 or higher for Singapore and 0.57 or higher for Lagos. These results satisfy convergent and discriminant validities (Rainer and Harrison, 1993).

\section{DESCRIPTIVE ANALYSIS}

Table 3 reveals that $62.1 \%$ and $64.4 \%$ of the respondents from Singapore and Lagos, respectively, have worked with the firm for more than 5 years and thus can be considered well-informed on the firm/industry and associated issues this paper addresses (Uma, 1992). Also, the table depicts that $58.6 \%$ and $56.3 \%$ of the firms in Singapore and Lagos financial industry, respectively, invest $6 \%$ and over annually on EC systems, indicating relatively high percentages. An approximately equal percentage revealed using EC for more than 8 years, indicating a relatively high level of experience. 
Table 3: Profile of Respondents

\begin{tabular}{||l|l|l|l||}
\hline \hline \multirow{2}{*}{ Item } & \multirow{2}{*}{ Value } & Singapore & Lagos \\
\cline { 3 - 4 } & & Average Percent of Respondents & Average Percent of Respondents \\
\hline Number of years with Firm & $>5$ years & $62.1 \%$ & $64.4 \%$ \\
\hline Number of Employees & $>500$ & $58.3 \%$ & $56.0 \%$ \\
\hline Annual Revenue & $>\mathrm{S} \$ 500 \mathrm{~m}$ & $62.1 \%$ & $49 \%$ \\
\hline EC Usage Period & $\geq 8$ years & $46.6 \%$ & $48 \%$ \\
\hline Annual Expenditure on EC & $\geq 6 \%$ & $58.6 \%$ & $56.3 \%$ \\
\hline
\end{tabular}

Number of cases: Singapore $=58 ;$ Lagos $=48$

As Table 4 reveals, perceptions of respondents in Singapore on the issues were, generally positive and stronger compared with perceptions among respondents in Lagos. However, while the percentage of respondents' who perceive government's policies on the specific issues to be encouraging were mostly lower among Lagos firms, competition policy and R\&D subsidies emerged short of expectation among firms in Singapore considering the robust information infrastructure and the high awareness programmes associated with the city.

Table 4: Regulatory and Policy Issues in Singapore and Lagos

\begin{tabular}{||l|l|l|l||}
\hline Factors & No Effect & Discouraged & Encouraged \\
\hline Telecom Infrastructure: & $10.3(20.8)$ & $24.1(35.2)$ & $65.5(44.0)$ \\
\hline Communication cost & $0(20.8)$ & $20.7(20.6)$ & $79.3(57.6)$ \\
\hline Network reliability & $6.9(28.0)$ & $25.9(35.2)$ & $67.2(36.8)$ \\
\hline Competition between operators & $1.7(24.0)$ & $17.2(39.2)$ & $81.0(36.8)$ \\
\hline Interoperability of networks & \multicolumn{1}{l||}{} \\
\hline Regulatory Factors: & $0(21.2)$ & $25.9(20.0)$ & $74.1(58.8)$ \\
\hline Transaction security & $0(18.6)$ & $0(20.6)$ & $91.4(60.8)$ \\
\hline Certification of payment & $8.6(10.8)$ & $3.4(36.0)$ & $87.9(53.2)$ \\
\hline Regulation of e-transactions & $15.5(34.8)$ & $15.5(38.0)$ & $69.0(27.2)$ \\
\hline Protection of intellectual property & $1.7(27.6)$ & $50.0(47.6)$ & $48.3(24.8)$ \\
\hline Policy Issues & $0(34.0)$ & $20.7(28.4)$ & $79.3(37.6)$ \\
\hline R\&D subsidies & $13.8(19.2)$ & $32.8(42.4)$ & $53.4(38.4)$ \\
\hline Awareness programs & $0(27.6)$ & $17.2(34.8)$ & $82.8(37.6)$ \\
\hline Competition policy & \multicolumn{2}{|l||}{} \\
\hline Electronic government models
\end{tabular}

Percentages in parenthesis are for Lagos

The Nigeria Communication Commission responsible for injecting competition in the telecommunication sector respond to these concerns by adopting policies aimed at reducing the adverse impact of the monopolistic status of Nigeria Telecommunication (NITEL) by issuing operating licenses to local and foreign investors willing and capable to increase the intensity of competition among the information technology operators. Regarding Singapore, IDA has been able to develop relatively solid competitive conditions in the sector, which would yield dividends in the near future.

Table 5: Means for Variables by Industry/City

\begin{tabular}{|c|c|c|c|}
\hline Singapore Financial Industry & Mean & Lagos Financial Industry & Mean \\
\hline $\begin{array}{l}\text { Business Environment } \\
\text { Perceived stability } \\
\text { Technology change }\end{array}$ & $\begin{array}{l}4.06 \\
3.87\end{array}$ & $\begin{array}{l}\text { Business Environment } \\
\text { Perceived stability } \\
\text { Technology change }\end{array}$ & $\begin{array}{l}2.66 \\
3.20\end{array}$ \\
\hline $\begin{array}{l}\text { Input } \\
\text { EC functionality } \\
\text { EC expertise }\end{array}$ & $\begin{array}{l}3.01 \\
2.92 \\
\end{array}$ & $\begin{array}{l}\text { Input } \\
\text { EC functionality } \\
\text { EC expertise }\end{array}$ & $\begin{array}{l}2.89 \\
2.96 \\
\end{array}$ \\
\hline $\begin{array}{l}\text { Output } \\
\text { Responsiveness }\end{array}$ & $\begin{array}{ll} & 3.72 \\
3.74 & \end{array}$ & $\begin{array}{l}\text { Output } \\
\text { Responsiveness }\end{array}$ & $\begin{array}{ll} & 3.56 \\
3.31 & \end{array}$ \\
\hline
\end{tabular}




\begin{tabular}{|c|c|c|c|}
\hline $\begin{array}{l}\text { Number of customers } \\
\text { Overall growth }\end{array}$ & $\begin{array}{l}3.35 \\
4.09\end{array}$ & $\begin{array}{l}\text { Number of customers } \\
\text { Overall growth }\end{array}$ & $\begin{array}{l}3.27 \\
4.17\end{array}$ \\
\hline $\begin{array}{l}\text { EC Activity } \\
\text { Routine activities } \\
\text { Core activities }\end{array}$ & $\begin{array}{l}4.28 \\
2.98\end{array}$ & $\begin{array}{l}\text { EC Activity } \\
\text { Routine activities } \\
\text { Core activities }\end{array}$ & $\begin{array}{l}4.18 \\
2.85\end{array}$ \\
\hline $\begin{array}{l}\text { Agglomeration Economies } \\
\text { Prod/Marketing via overseas } \\
\text { Shared value system }\end{array}$ & $\begin{array}{l}3.74 \\
4.10\end{array}$ & $\begin{array}{l}\text { Agglomeration Economies } \\
\text { Prod/Marketing via overseas } \\
\text { Shared value system }\end{array}$ & $\begin{array}{l}2.80 \\
3.40\end{array}$ \\
\hline
\end{tabular}

Table 5 depicts the composite mean values for five variables investigated in this study - business environment, EC activity, agglomeration economies, input, and output. Perspectives on Singapore and Lagos industries reveal some similarities, especially, with regard to input, and differences between composite means for business environment, agglomeration economies, output and EC activity (see Table 5). These results highlight the varying contextual features and underlying characteristics of the variables within Singapore and Lagos financial industries, particularly, on environmental factors. Input factors for the industries in Singapore and Lagos emerged with relatively less disparity as in overall growth and core activities.

\section{FINDINGS}

This section presents correlation analysis to establish any relationship among the dimensions of the constructs including any underlying strength and orientation among the dimensions. It also provides evidence crucial for determining the applicability of multiple regression analysis. Table 6 provides codes and descriptions of the factors we used in the preceding analysis.

The results in Table 7 reveal that firm-specific features, input, output, agglomeration economies, and EC activity, generally correlate positively. AEXPEC correlates with TECHANG, which implies that a firm would not favour investment in EC systems if it were not receptive to changes in information systems.

In addition, the results in Table 8 reveal that the variable dimensions, generally correlate weakly. For instance, RESPON correlates weakly with ECACT, which implies that a firm's responsiveness to customers' and suppliers' requests and orders relate marginally to the extent and number of activities performed using EC.

Although there were significant positive relationships among the variables in both industries in Singapore and Lagos, the correlation coefficients for industries in Lagos were generally weak compared to those for Singapore industries. In addition, results of Singapore sample reveal stronger relationships between the factors compared to Lagos study.

Table 9 indicates that the structural difference between Singapore and Lagos samples is significant at $p<0.05$ with respect to output $(t=4.434 ; p$-value $=0.000)$, EC activity $(t=2.321 ; p$-value $=$ $0.027)$, and business environment $(t=11.428 ; p$-value $=0.000)$, and to a lesser degree, input. On the other hand, there was no significant difference between the two industries on firm-specific features at $p<0.05(t=-1.617 ; p$-value $=0.109)$, which supports the descriptive result in Table 3 . The results in Table 9 indicate structural patterns and contexts, which are not only determined by firm and industry characteristics, but also by the specific distinct backgrounds and trajectories of Singapore and Lagos economic and social development processes. 
Table 6: Codes \& Descriptions of Variables

\begin{tabular}{|l|l||}
\hline CODES & Descriptions \\
\hline ISINFIN & Input for Singapore Financial Industry \\
\hline OSINFIN & Output for Singapore Financial Industry \\
\hline ESINFIN & Environment for Singapore Financial Industry \\
\hline ASINFIN & EC Activity for Singapore Financial Industry \\
\hline FSINFIN & Firm-Specific Features for Singapore Financial Industry \\
\hline ILAGFIN & Input for Lagos Financial Industry \\
\hline OLAGFIN & Output for Lagos Financial Industry \\
\hline ELAGFIN & Environment for Lagos Financial Industry \\
\hline ALAGFIN & EC Activity for Lagos Financial Industry \\
\hline FLAGFIN & Firm-Specific Features for Lagos Financial Industry \\
\hline SIZE & Annual Revenue (FIRM-SPECIFIC) \\
\hline ECTIME & Years of EC Usage in the Firm (FIRM-SPECIFIC) \\
\hline AEXPEC & Annual Expenditure on EC Systems (FIRM-SPECIFIC) \\
\hline ECACT & Activities Performed via EC (EC ACTIVITY) \\
\hline PERSTAB & Perceived Stability in Business Environment (CITY-SPECIFIC) \\
\hline TECHANG & Technology Change (CITY-SPECIFIC) \\
\hline CUSRET & Customer Retention (OUTPUT) \\
\hline RESPON & Responsiveness (OUTPUT) \\
\hline OVERAL & Overall Growth in Service Provision (OUTPUT) \\
\hline ECSFUN & EC Systems Functionality (INPUT) \\
\hline ECEXP & EC Expertise in the Firm (INPUT) \\
\hline
\end{tabular}

Table 7: Correlation Matrix for Firm-Specific Features, Business Environment, Input, EC Activities, Agglomeration Economies, and Output - SINFIN

\begin{tabular}{|c|c|c|c|c|c|c|c|c|c|c|c|c|}
\hline Variables & 1 & 2 & 3 & 4 & 5 & 6 & 7 & 8 & 9 & 10 & 11 & 12 \\
\hline \multicolumn{13}{|l|}{ 1. SIZE } \\
\hline 2. ECTIME & 0.756 & & & & & & & & & & & \\
\hline 3. AEXPEC & 0.835 & 0.722 & & & & & & & & & & \\
\hline 4. ECACT & 0.669 & 0.565 & 0.659 & & & & & & & & & \\
\hline 5. PERSTAB & n. s & 0.456 & 0.697 & 0.697 & & & & & & & & \\
\hline 6. TECHANG & n. $s$ & 0.261 & 0.598 & 0.766 & 0.889 & & & & & & & \\
\hline 7. CUSRET & n. $\mathrm{s}$ & 0.863 & 0.491 & 0.783 & 0.641 & 0.656 & & & & & & \\
\hline 8. RESPON & n. $\mathrm{s}$ & 0.769 & 0.754 & 0.811 & 0.738 & 0.578 & 0.714 & & & & & \\
\hline 9. OVERAL & n. $\mathrm{s}$ & 0.784 & 0.689 & 0.644 & 0.772 & 0.717 & 0.622 & 0.599 & & & & \\
\hline 10. ECSFUN & 0.761 & 0.822 & 0.887 & 0.564 & 0.692 & 0.687 & 0.659 & 0.676 & 0.748 & & & \\
\hline 11. ECEXP & 0.896 & 0.799 & 0.703 & 0.630 & 0.745 & 0.705 & 0.504 & 0.729 & 0.561 & 0.649 & & \\
\hline 12. PRORE & 0.723 & 0.592 & 0.601 & 0.432 & 0.679 & 0.665 & n. s & 0.432 & 0.346 & 0.395 & 0.276 & \\
\hline 13. VALUES & 0.632 & 0.610 & 0.545 & 0.534 & 0.712 & 0.541 & n. $\mathrm{s}$ & 0.329 & 0.290 & 0.223 & 0.439 & 0.657 \\
\hline
\end{tabular}

The results of bivariate step-wise multiple regression analysis indicate that the perceived relationships among output, business environment, input and EC activity among Singapore and Lagos firms are mix (see Table 10). Eight of the nine path coefficients for Propositions 2, 3 and 4 in Singapore and Lagos industries were significantly different from zero at $0.05 \%$ significance level (see Table 10). All the outcomes had reasonably large standardized coefficients with the expected signs except for Propositions $3 \mathrm{~b}, 4 \mathrm{a}$ and $4 \mathrm{c}$ that indicate weak relationships. The results from the two 
locations did not support the proposed relationship depicting output as a function of firm-specific features. In addition, Proposition 5 emerged significant for Singapore study at $p<0.05(R 2=0.86 ; p$ value $=0.000)$ and Lagos $(R 2=0.53 ; p$-value $=0.013)$, respectively $)$. The result for Lagos emerged relatively weak, which is not surprising. These results indicate that firms' EC systems and related resources have the potential to enhance the agglomeration ability that industries in a city can harness, which may improve the synergistic relationships among firms. By implication, that Singapore's strong economic structure and decades of government's commitment towards promoting the island as a regional hub for financial and ICT operations, markedly differentiates it from Lagos.

\section{TABLE 8: CORRELATION MATRIX FOR FIRM-SPECIFIC FEATURES, INPUT, BUSINESS ENVIRONMENT,}

EC Activities, Agglomeration Economies, and Output - LAGFIN

\begin{tabular}{||l|c|c|c|c|c|c|c|c|c|c|c|c||}
\hline \hline Variable & $\mathbf{1}$ & $\mathbf{2}$ & $\mathbf{3}$ & $\mathbf{4}$ & $\mathbf{5}$ & $\mathbf{6}$ & $\mathbf{7}$ & $\mathbf{8}$ & $\mathbf{9}$ & $\mathbf{1 0}$ & $\mathbf{1 1}$ & $\mathbf{1 2}$ \\
\hline 1. SIZE & & & & & & & & & & & & \\
\hline 2. ECTIME & 0.343 & & & & & & & & & & & \\
\hline 3. AEXPEC & 0.676 & 0.211 & & & & & & & & & & \\
\hline 4. ECACT & 0.321 & 0.197 & 0.321 & & & & & & & & & \\
\hline 5. PERSTAB & n. s & 0.103 & 0.429 & 0.345 & & & & & & & & \\
\hline 6. TECHANG & n. s & n. s & 0.328 & 0.467 & 0.324 & & & & & & & \\
\hline 7. CUSRET & n. s & 0.511 & 0.467 & 0.625 & 0.425 & 0.329 & & & & & & \\
\hline 8. RESPON & n. s & 0.612 & 0.679 & 0.522 & 0.326 & 0.317 & 0.211 & & & & & \\
\hline 9. OVERAL & n. s & 0.421 & 0.662 & 0.456 & 0.446 & 0.226 & 0.450 & 0.345 & & & & \\
\hline 10. ECSFUN & 0.451 & 0.674 & 0.712 & 0.345 & 0.302 & 0.428 & 0.477 & 0.476 & 0.435 & & & \\
\hline 11. ECEXP & 0.567 & 0.347 & 0.511 & 0.424 & 0.221 & 0.529 & 0.502 & 0.395 & 0.341 & 0.512 & & \\
\hline 12. PRORE & 0.342 & 0.495 & 0.267 & 0.324 & 0.435 & 0.532 & n. s & 0.432 & 0.435 & 0.300 & 0.387 & \\
\hline 13. VALUES & 0.453 & 0.542 & 0.475 & 0.322 & 0.511 & 0.397 & n. s & 0.546 & 0.346 & 0.492 & 0.401 & 0.702 \\
\hline
\end{tabular}
48

All correlations are Significant at $p<0.05$, unless otherwise noted as not significant. Number of Cases $=$

Table 9: Test Summary for Proposition 1

\begin{tabular}{||l|c|c|c||}
\hline \hline \multicolumn{1}{|c|}{ Proposition } & Parts of Proposition & $\boldsymbol{T}$ & $\boldsymbol{p}$-value \\
\hline \multirow{3}{*}{$\begin{array}{l}\text { P1. There would be significant positive } \\
\text { structural differences between Singapore } \\
\text { and Lagos financial industries. }\end{array}$} & Output for LAG - Output for SIN & $4.434 *$ & 0.000 \\
\cline { 2 - 4 } & Input for LAG - Input for SIN & $2.442 *$ & 0.018 \\
\cline { 2 - 4 } & BE for LAG - BE for SIN & $11.428^{* * *}$ & 0.000 \\
\cline { 2 - 4 } & FSF for LAG - FSF for SIN & -1.617 & 0.109 \\
\cline { 2 - 4 } & ECA for LAG - ECA for SIN & $2.321 *$ & 0.027 \\
\hline
\end{tabular}

$L A G=$ Lagos; $S I N=$ Singapore $; F S F=$ Firm-specific Features; $E C A=E C$ Activity; BE $=$ Business Environment

These results are particularly significant because through the 1990s until to date, Singapore has taken strong strategic steps to remain competitive in the regional and global marketplace by promoting the island as a centre for industrial operations (see earlier notes). Nonetheless, it is insufficient for Singapore to be a nodal point for the attraction of overseas capital, skills, knowledge and other resources, it is also crucial for Singapore to expand and grow its regional market including Africa and Latin America. In addition to the strategies Singapore government adopted to maintain the island's competitiveness including the Connected Singapore initiative, this research highlights and advocates more aggressive deployment of EC technologies in firms. With the existing infrastructural capabilities in place, it [EC] would be a great asset to enhance and advance firms' collaboration in the production and marketing of goods and services within the global marketplace framework.

These results imply that the success of a firm and industry may depend on the economic processes in a particular societal context. Hence, the playing field upon which places compete is uneven. Cities, for example, have distinctive characteristics and histories, and situate differently within the larger 
political economy based specifically on at least two dimensions, each of which tilts the playing field to favour some cities over others: enabling system and historical trajectories. First, firms found in places where the state favours capitalist approach, institutes policies that promote industrial competitiveness, facilitates well-trained and motivated workforce, and provides enabling EC and related infrastructure have greater possibilities to gain competitive advantages from the particulars of their systems (Sheppard, 2000). Secondly, each city occupies a unique geographical trajectory because of its historical role and location within the broader political and economic systems, a uniqueness that creates differences in the ability of individual cities to respond to economic and political restructuring. However, the total implications and directions of these results may be unclear. Nonetheless, firm-specific features did not predict output in both study areas, although both variables correlate. The financial industry has a strong history and tradition of information systems implementation because of its task requirements. Consequently, the industry would require concrete and strategic investment and usage of advanced information systems to maintain positive significant progress in operational and strategic efficiencies. 
Table 10: Test Summary for Propositions 2-4

\begin{tabular}{|c|c|c|c|c|}
\hline Source & $\boldsymbol{R 2}$ & $b, t$-ratio & $p$-value (a) & Std. Coef. \\
\hline \multicolumn{5}{|l|}{ Proposition 2a: Output on Input } \\
\hline Output contingent on Input - SIN & 0.819 & $0.494(15.893) * * *$ & 0.000 & 0.905 \\
\hline Output contingent on Input - LAG & 0.689 & $0.401(16.494) * * *$ & 0.000 & 0.767 \\
\hline \multicolumn{5}{|c|}{ Proposition 2b: Output on Business Environment } \\
\hline Output contingent on $\mathrm{BE}-\mathrm{SIN}$ & 0.822 & $0.830(16.092) * * *$ & 0.000 & 0.907 \\
\hline Output contingent on $\mathrm{BE}-\mathrm{LAG}$ & 0.681 & $0.750(16.204)^{* * *}$ & 0.000 & 0.855 \\
\hline \multicolumn{5}{|c|}{ Proposition 2c: Output on EC Activity } \\
\hline Output contingent on ECA - SIN & 0.890 & $0.257(21.332) * * *$ & 0.000 & 0.944 \\
\hline Output contingent on ECA - LAG & 0.785 & $0.245(21.178)^{* * *}$ & 0.000 & 0.881 \\
\hline \multicolumn{5}{|c|}{$\begin{array}{ll}\text { Proposition 2d: Output on Firm Specific Feature } \\
\end{array}$} \\
\hline Output contingent on FSF - SIN & 0.067 & $0.442(1.023)$ & 0.254 & 0.076 \\
\hline Output contingent on FSF - LAG & 0.075 & $0.054(1.296)$ & 0.121 & 0.117 \\
\hline \multicolumn{5}{|c|}{$\begin{aligned} \text { Proposition 3a: Input on Business Environment } \\
\end{aligned}$} \\
\hline Input contingent on $\mathrm{BE}-\mathrm{SIN}$ & 0.838 & $1.536(17.047)^{* * *}$ & 0.000 & 0.816 \\
\hline Input contingent on $\mathrm{BE}-\mathrm{LAG}$ & 0.742 & $1.619(18.787)^{* * *}$ & 0.000 & 0.818 \\
\hline \multicolumn{5}{|c|}{$\begin{aligned} \text { Proposition 3b: Input on Firm Specific Feature } \\
\end{aligned}$} \\
\hline Input contingent on FSF - SIN & 0.501 & $1.356(15.226)^{* * *}$ & 0.000 & 0.510 \\
\hline Input contingent on FSF - LAG & 0.642 & $1.459(16.080)^{* * *}$ & 0.000 & 0.472 \\
\hline \multicolumn{5}{|c|}{$\begin{array}{c}\text { Proposition 4a: EC Activity on Business Environment } \\
\end{array}$} \\
\hline ECA contingent on $\mathrm{BE}-\mathrm{SIN}$ & 0.852 & $3.096(17.939)^{* * *}$ & 0.000 & 0.923 \\
\hline ECA contingent on $\mathrm{BE}-\mathrm{LAG}$ & 0.716 & $2.782(17.613)^{* * *}$ & 0.000 & 0.846 \\
\hline \multicolumn{5}{|c|}{ Proposition 4b: EC Activity on Input } \\
\hline ECA contingent on Input - SIN & 0.329 & $0.427(2.702)^{*}$ & 0.019 & 0.410 \\
\hline ECA contingent on Input - LAG & 0.309 & $0.329(2.309)^{*}$ & 0.020 & 0.297 \\
\hline \multicolumn{5}{|c|}{$\begin{aligned} \text { Proposition 4c: EC Activity on Firm Specific Feature } \\
\end{aligned}$} \\
\hline ECA contingent on FSF - SIN & 0.532 & $1.411(11.101)^{* * *}$ & 0.000 & 0.449 \\
\hline ECA contingent on FSF - LAG & 0.385 & $1.209(9.311)^{* *}$ & 0.001 & 0.334 \\
\hline
\end{tabular}

$L A G=$ Lagos; SIN= Singapore; FSF= Firm-specific Feature; ECA= EC Activity; BE= Business

Environment

\section{DISCUSSION}

Clearly, the patterns of relationships that emerge among the constructs for Singapore and Lagos firms demonstrate strong influence of the environment in which the firms operate evident from the strength of the relationships among the variables and the varying results between the two cities. In theory, location should no longer be a source of competitive advantage as open global markets, rapid transportation, and high-speed communications systems tend to equalize any differences. However, in practice, location and largely, regional imperatives remain central to national and global industrial competition. Consequently, a city's infrastructural capabilities in terms of high quality expertise, capital, sophisticated knowledge management tools and the ability of firm to integrate strategically these resources for potential benefits are key differentiating factors in contemporary and future global competition. It is pertinent to note, however, that technological factor is the key resource in this paper. The complementary nature of this factor, as Zhuang (2000) observed, would be insufficient to explain all the possible outcomes in this comparison. Overall, while firm resources are important determinants for operational activities, technological opportunities and local imperatives are equally significant. The structural differences between the two industries mirror the distinct trajectories of the cities and their influence on associated business performances. Consistent with Porter's (1990) view, our findings demonstrate the importance of sophisticated factor conditions in a city, which enable accelerated development processes in the specific industry including the potential roles of EC. Accordingly, although the EC phenomenon is global in character and certainly requires firms to implement effective international information infrastructure standards, the potential benefits of EC have a distinct geography as development processes, efficient 
governance, information systems policies, and pervasive deployment of EC technologies differ across the globe.

\section{IMPLICATIONS FOR RESEARCH}

We examined empirically the paths among the constructs and received modest support, which could be useful resources for future research development in EC and firms. In addition, our finding is consistent with evolving academic models of technology-firm-environment framework expanded by Zhu et al. (2002) in new substantive areas - Singapore and Lagos. In this regard, it extends the field of information systems, EC, and the geographic concentration of industries consistent with Porter's (1998) analysis. We are optimistic that as the subject area develops further particularly in theoretical and methodological approaches specific to EC research, future studies based on the procedures we used would receive greater empirical support. Since EC is still evolving with just a few studies focusing on theory and framework building, our findings and design processes represent modest contributions to research, and may be useful in strengthening the theoretical and operational directions of future researches regarding the roles of EC in industrial developments of cities. Although this research focuses on firms in the financial industries in Lagos and Singapore, our findings appear to have implications for financial firms operating in business environments, which share similar characterization as our sample. Taking into account the effects of business tradition and the extent of EC deployment in firms, this research is replicable to financial industries in Hong Kong/Johannesburg or Accra/Hong Kong. The heightened notion of digital economy and its pervasive influence on the structure of industries makes a case for applicability in this research.

\section{IMPLICATIONS FOR PRACTICE}

Firms could, based on our findings, effectively configure their inputs for efficient business activities and functional associations among partners and customers. The results demonstrate significant positive relationships among some of the constructs suggesting that with adequate configurations of EC, business activities tend to improve given a favourable business environment. Managers may use our procedure to assess the success of EC strategies in their respective firms by determining the strengths of the relationships among the various constructs. They can also assess their successes with each factor against corporate goals. Further, managers may compare data from their firm against normalized data across related firms, which would enable them to compare the scores for their firms with those of the industry. In addition, this research provides an expanded understanding of Zhuang's (2000) resource-based view of the firm using EC applications as the key factors to address business operations, with specific reference to the cities and industries we investigated. This understanding would be useful to managers who may need to adapt the input-based view in making similar analysis, for instance, in identifying the strategic roles of EC for enhancing business operations and performance of firms in specific contexts. We are aware that correlation is not causation; yet, managers may still consider the quality of EC systems in their firms. Perhaps, by examining the sub-dimensions of the constructs and the effects of EC under distinct conditions, managers may be encouraged to improve their EC strategies, which will probably translate into better overall industrial performance.

\section{IMPLICATIONS FOR POLICY}

Greater practical and effective government policies in the two cities, particularly Lagos, would be important to make it easier and more affordable to firms in the private sector to deploy EC systems in their industries. Policies that would encourage competition among Internet Service Providers (ISPs) and related operators in the sector would consequently boost investment in the IT sector, which may have spillover effects on industrial operations and overall economic performance. This, among other initiatives, would create attractive sites for regional business development, particularly small businesses, which could drive foreign direct investment. As globalization and competitive pressures force governments to rethink conventional modes of administration, there may be no other 
innovative strategy for government agencies in Lagos to achieve operational effectiveness but to employ adequately EC systems in key activities, particularly in the administration of public goods.

\section{AGENDA FOR FUTURE STUDIES}

Longitudinal investigations designed to answer critical questions on specific dynamics of the interplay of EC and the firms' competitive functions in divergent business landscapes would be very useful to provide additional insights on the conceptual framework. In addition, this research relied primarily on perceptual data. Future research should consider personal interviews as they might provide additional information on the variables. However, Dess and Robinson (1984) argue that subjective data tend to correlate strongly with objective data. A case study employing qualitative research approach would be useful for greater appreciation of the overall framework development, and new managerial insights on the nature of EC strategy.

\section{REFERENCES}

Afuah, A. \& Tucci, C.L. (2001) Internet Business Models and Strategies: Text and Cases, Boston, MA: McGraw-Hill.

Amin, A. \& Thrift, N. (1997) Globalization, Socio-economics, and Territoriality, in, R. Lee, and J. Wills (eds.), Geographies of Economies, London: Arnold, pp 76-99.

Anderson, J.C. \& Gerbing, D.W. (1988) "Structural Equation Modelling in Practice: a Review and Recommended Two-step Approach”, Psychological Bulletin, Vol 103, pp 411-423.

Ansoff, H.I. \& Sullivan, P.A. (1993) "Optimizing Profitability in Turbulent Environments: A Formula for Strategic Success", Long Range Planning, Vol 26, No 5, pp 11-23.

Bain, J.S. (1959) Industrial Organization, New York: Wiley \& Sons.

Barney, J. (1991) "Firm Resources and Sustained Competitive Advantage", Journal of Management, Vol 17, No 1, pp 99-120.

Bentler, P.M. \& Bonett, D.G. (1980) "Significance Test and Goodness of Fit in the Analysis of Covariance Structures", Psychological Bulletin, Vol 88, pp 588-606.

Bird, A. \& Lerhman, W.G. (1993) "The Effects of Information Technology Adoption in Japanese Corporations", Japan and World Economic Journal, Vol 5, pp 217-242.

Carmines, E. \& Mclver, J. (1981) "Analysing Models with Unobserved Variables: Analysis of Covariance Structures", In, Bohrnstedt G. Borgatta E. (eds), Social Measurement: Current Issues, Beverly Hills, CA: Sage, pp 65-115.

Chandler, G.N. \& Hanks, S.H. (1994) "Market Attractiveness, Resource-based Capabilities, Venture Strategies and Venture Performance", Journal of Business Venturing, Vol 9, pp 331-349.

Conner, K.R. (1991) "A Historical Comparison of Resource-based Theory and Five Schools of Thought within Industrial Economics: Do we have a new Theory of the Firm?", Journal of Management, Vol 17, No 1, pp 121-154.

Debreceny, R.; Putterill, M.; Tung, L.L.; \& Gilbert, A.L. (2002) "New tools for the Determination of E-commerce Inhibitors", Decision Support Systems, Vol 34, pp 177-195.

Dess, G.G. and Robinson, R.B. (1984) "Measuring Organizational Performance in the Absence of Objective Measures: The Case of Privately-held Firm and Conglomerate Business Unit", Strategic Management Journal, Vol 5, pp 265-273.

Dicken, P. \& Lloyd, P.E. (1990) Location in Space: Theoretical Perspectives in Economic Geography, 3rd ed., New York: Harper Collins Publishers.

Downey, H.K., \& Slocum, J.W. (1982) "Managerial Uncertainty and Performance", Social Science Quarterly, Vol 63, No 2, pp 195-207.

Eze, U.C. (2004) A Contextual Perspective of E-commerce Across Borders and Industries: Comparing Perceptions of the IT and Financial Services Industries in Singapore and Nigeria, PhD Dissertation, Nanyang Technological University, Singapore. 
Gatian, A.W., Brown, R.M., \& Hicks, J.J.O.Jr. (1995) "Organizational Innovativeness, Competitive Strategy and Investment Success”, Journal of Strategic Information Systems, Vol 4, No 1, pp 43-59.

Gebauer, J. \& Scharl, A. (1999) "Between Flexibility and Automation: an Evaluation of Web Technology from a Business Process Perspective", Journal of Computer-Mediated Communication, Vol 5, No 2, pp 1-18.

Gilbert, L.A., Kendall, J., Soh, C., \& Tung, L.L. (1999) "Perceived Barriers to the Widespread Commercial Use of the Web", presented to the AusWeb99, the Fifth Australian World Wide Web Conference, Ballina, NSW.

Grant, R.M. (1991a) "The Resource-Based Theory of Competitive Advantage: Implications for Strategy Formulation", California Management Review, pp 114-135.

Hamel, G. \& Sampler, J. (1998) "The E-Corporation”, Fortune, 7, p 80.

Hepworth, M.E. (1990) Geography of the Information Economy, New York: Gilford Press.

IDA. (2001) Quarterly Report on E-commerce Development in Singapore.

Kettelhut, M.C. (1992) "Strategic Requirements for IS in the Turbulent Healthcare Environment", System Management, Vol 43, No 6, pp 6-10.

Lee, M.C.S. \& Adams, D.A. 1990 “A Manager's Guide to the Strategic Potential of Information Systems", Information and Management, Vol 19, pp 169-182.

Leinbach, T.R. \& Brunn, S.D. (2001) "Introduction: E-commerce: Definitions, Dimensions and Constraints", in, Leinbach, T.R. and Brunn, S.D. (eds.), Worlds of E-commerce: Economic, Geographic and Social Dimensions, Chichester: John Wiley \& Sons.

Mahmood, M. \& Soon, S.K. (1991) "A Comprehensive Model for Measuring the Potential Impact of Information Technology on Organizational Strategic Variables”, Decision Sciences, Vol 22, pp 869-897.

McDougall, P., Phillips, P.; Covin, J.G., Robinson, R.B.Jr., \& Herron, L. (1994) "The Effect of Industry Growth and Strategic Breadth on New Venture Performance and Strategy Content", Strategic Management Journal, Vol 15, No 7, pp 537-554.

Penrose, E. (1959) The Theory of Growth of the Firm, New York: John Wiley \& Sons.

Plummer, P. \& Taylor, M. (2001) "Theories of Local Economic Growth: Concepts, Models, and Measurement", Environmental Planning, A, No 33, pp 219-236.

Plummer, P. \& Taylor, M. (2000) "Theory and Praxis in Economic Geography: Enterprising' and Local Growth in a Global Economy”, Presentation at the Wisconsin Economic Summit, Midwest Express Centre, Milwaukee, Wisconsin, November 29-December 1, pp 23-41.

Powell, T.C. \& Dent-Micallef, A. (1997) "Information Technology as Competitive Advantage: The Role of Human, Business, and Technology Resources", Strategic Management Journal, Vol 18, No 5, pp 375-405.

Porter, M.E. (1990) The Competitive Advantage of Nations, New York: Free Press.

Porter, M.E. (1998) "Clusters and the New Economies of Competition”, Harvard Business Review, Boston.

Porter, M.E. (2001) "Strategy and the Internet”, Harvard Business Review, March, pp 62-78.

Prahalad, C.K. \& Hamel, G. (1990) "The Core Competence of the Corporation”, Harvard Business Review, Vol 68, No 3, pp 79-91.

Rai, A. (1997) "Technology Investment and Business Performance", Communications of the ACM, Vol 40, pp 89-97.

Rainer, R.E. \& Harrison, A.W. (1993) "Toward Development of the End User Computing Construct in a University Setting”, Decision Sciences Journal, Vol 24, pp 1187-1202.

Rowsom, M. (1998) "Bridging the Gap from Traditional Marketing to Electronic Commerce", Direct Marketing, Vol 60, No 9, pp 23-25.

Sheppard, E. (2000) "Competition in Space and between Places", in, E. Sheppard and T.J. Barnes, A Companion to Economic Geography, (eds.), Massachusetts: Blackwell, pp 171-186.

Sundell, R.A. (1999) Relationship among Types of Information Technology Structures, Business Environments, Electronic Commerce and Financial Performance. D.B.A. Dissertation, United States International University, San Diego. 
Trippi, R.R. \& Salameh, T.T. (1989) "Strategic Information Systems: Current Research Issues", Journal of Information Systems Management, Vol 6, No 3, pp 30-35.

Tham, I. (2002) "E-commerce Activities in Singapore are Bucking the Recession Trend, a Government Survey revealed", (http://news.com.com/2100-1017-853304.html).

Ujah, E. (2001) "Electronic Commerce and Small Business Development in Nigeria", Nigeria Business Times, Monday 17th, September.

Ujah, E. (1999) "Keeping up with the Growth in Nigeria IT Industry", Nigeria Business Times, Monday 2nd, May, p 12.

Uma, S. (1992) Research Methods for Business, 2nd ed., New York: John Wiley \& Sons.

Waddock, S.A. \& Isabella, L.A. (1989) "Strategy, Beliefs about the Environment, and Performance in Banking Simulation", Journal of Management, Vol 15, No 4, pp 617-632.

Zaheer, A. \& Zaheer, S. (1997) "Catching the Wave: Alertness, Responsiveness, and Market Influence in Global Electronic Networks", Management Science, Vol 43, No 11, pp 1493-1509.

Zhuang, Y. (2000) A Resource-Based View of Electronic Commerce, Ph.D. Dissertation, University of Kentucky.

Zhu, K.; Kraemer, K.L.; \& Xu, S. (2002) “A Cross-Country Study of Electronic Business Adoption Using the Technology-Organization-Environment Framework", presented to the Twenty-Third International Conference on Information Systems, Barcelona, pp 337-348.

Zwass, V. (2003) "Electronic Commerce and Organizational Innovation: Aspects and Opportunities", International Journal of Electronic Commerce, Vol 7, No 3, pp 7-37. 